\title{
Gender Differences among Economically Active University Graduates*
}

\author{
MARIE ČERMÁKOVÁ ${ }^{* *}$ \\ Institute of Sociology, Academy of Sciences of the Czech Republic, Prague
}

\begin{abstract}
This article looks at the areas of difference in the positions of men and women with university degrees in Czech society. It uses the results of a project entitled "Men and Women University Graduates" and other available statistical data. 1 The comparison between men and women graduates and between women graduates and women with other levels of education provides a picture of the specific position of women graduates on the labour market. The article looks at the possibilities of studying gender differences and the specific status of women in a transitional society. The analysis concentrates on two basic areas - (a) that of salary differences, and (b) that of attitudes to performance and career. The author develops the thesis that the continuing gender differences between men and women graduates cannot be attributed to the nature of the female work force. The secondary position of these women on the labour market is due to non-economic factors. Aspects discussed include the existing guarantees for equality of men and women in Czech society, the double standard of university qualifications, the link between the universityeducated female labour force and the female sectors of the labour market, the factor of the "unclear identity" of women graduates, and that of the low level of emotional support from these women's social surroundings. The article also looks at individualised, personalised ways of creating a social position that are used by women graduates on the market or in their career, and highlights the fact that these approaches are both risky and ineffective in the search for equal status or the implementation of equal opportunities policies.
\end{abstract}

Czech Sociological Review, 1999, Vol. 7 (No. 2: 127-144)

In this article I would like to draw attention to the continuing differences in the position at work of men and women university graduates, by considering certain indicators of salary differences and attitudes to questions of career and performance. I will also consider the

\footnotetext{
*) This research was supported by grant no. 403/97/0586 "The Position of Women Graduates in Czech society in the 1990s" from the Grant Agency of the Czech Republic.

**) Direct all correspondence to: PhDr. Marie Čermáková, Institute of Sociology of the Academy of Sciences of the Czech Republic, Jilská 1, 11000 Praha 1, e-mail cermako@soc.cas.cz

1) In 1998 the Sociological Institute of the Czech Academy of Sciences carried out a representative sociological survey into "Men and Women University Graduates", as part of the project, "The Position of Women Graduates in Czech Society in the 1990s" (GA ČR č. 403/97/0586). The data was collected by the Sofres-Factum agency. The survey was intended to gain a wide-ranging view of the life and work of men and women graduates, comparing men's and women's working and social conditions, mapping gender inequalities and stereotypes of these from the point of view of educational attainment in the elites of Czech society. The representative samples included 1908 economically active respondents, of which 947 (49.6\%) were women and 961 (50.4\%) men. The sample was representative by age, the distribution of university education and type of place where the respondent lived. More than $95 \%$ of both men and women had a post-graduate or professional degree.
} 
differences between women with and without a university education. I am particularly interested in the role of women, in this case those working women graduates, in the process of individual and group work and social advancement in a society in transition.

\section{The Possibilities of Studying Gender Differences}

Some economic theories, such as the neo-classical or institutional ones, provide justifications for the unequal position of men and women on the labour market. According to these the very nature of the female labour force means that it offers a lesser labour capital and higher cost (e.g. with respect to legal and social insurance). It is therefore both economic and right that it should have lesser value, since it is less productive than that of men. Institutional theories presuppose a dual labour market, or as many markets as there are segments of the national economy and gender differences further highlight the differences between the male and female labour forces. They see these as lying primarily in the educational capital and flexibility of the labour force and this leads to the segregation of men and women into certain professions [Anker 1998]. These theories do not explain the origins of the segregation, as they are not concerned with influences and actors from outside the economy. These are, however, indicated and interpreted by various genderrelated or feminist approaches [Anker 1998, Abbot and Wallace 1997, Rubery 1998, Rees 1998, Jacobs 1995, Hakim 1996, Šanderová 1999] which argue that women's position on the labour market is the result of patriarchal social ties and the subordination of women in society and in the family. These theories assume that women are more likely to be found in those parts of the labour market with lower competence, lower work status, and also work with less social prestige.

One major methodological problem arises in comparing the overall level of gender differences with those in developed European countries (and possibly the USA). Apart from statistical surveys of salary levels and the basic set of selective surveys on the structure and movement of the labour force, there are no long-term analyses in the Czech Republic of the type available in, for example, the OECD countries. This article is therefore largely based on sociological data and analysis. Gender theories are an important concept for comparison but are not sufficient to explain the situation in a society in transition. Analyses of the social position of women in the Czech Republic [Čermáková 1995, $1997 \mathrm{a}, \mathrm{b}]$ have cast a certain doubt on the simple declaration of a "dual burden" or "exploitation of women" and demonstrated a number of distinctions in the social development of the female population in this country between 1945 and 1989, which determine not only the current social status of women, but particularly the position and behaviour of working women in the 1990s. It can be hypothesised that both the framework of the system (i.e. the labour market, social system, gender relations, political decisions, etc.) and the activity of women (attitudes, behaviour, approaches, etc.) determine the subsequent level (degree) of the social status of Czech women, but at the present time and in the conditions of a society in transition it is difficult to empirically delineate the relation between these two (i.e. between the system and the actor). 


\section{The Position of Czech Women}

The situation of women in the Czech Republic differs from that in developed democracies primarily in that there is no legislation directly protecting them against discrimination. ${ }^{2}$ Nor is there an established principle of equal remuneration of men and women, or of equal pay for work of equal value. ${ }^{3}$ There is a relatively large number of provisions relating to social protection for working women with children under the age of four, including the length of maternity leave ( 28 weeks), the length of extended maternity leave (up to the child's fourth birthday), various other social provisions protecting women with small children (sickness insurance), and a network of nursery schools and after-school care. ${ }^{4}$

The situation in the Czech Republic is distinguished by the following:

- long-lasting female employment, i.e. over several generations, with a clear trend towards a rising education and professional structure;

- the presence of women in all professions at all levels, although the percentage of women ranges from $2 \%$ to $19 \% ; 5$

- women work in the both the private and state sectors and in all branches of the economy, and account for $22 \%$ of entrepreneurs employing other staff;

- a large majority (i.e. over $80 \%$ ) of women work full time (i.e. 42.5 hours per week);

$-3 \%$ of women also have a second job;

- the classical pure model of a housewife (that is, of a woman dependent on her husband's income) is rare (not more than $1 \%$ of women of working age);

- Czech women spend more time at work than women in any other country ["Emerging..." 1999]. ${ }^{6}$

In addition to the above factors, the fact that the Czech Republic is a country in transition is also significant [Machonin and Tuček 1996]. The processes now under way are shaped by economic crisis and political rigidity, unemployment is rising and the first priority is

2) The equality of men and women is guaranteed by the Czech constitution, but in this article the stress is on practice in this country, where there is a lack of any explicit ban on discrimination against women.

3) Among politicians, doubts are cast on the value of introducing such provisions by pointing to the meagre returns which such provisions have brought to women in, for example, the countries of the EU over recent decades.

4) The network of day care centres and nursery schools has been considerably reduced since 1989, but in view of the present number of children it cannot be said to have been decimated. There are, however, considerable differences between the possibility of finding a nursery school place in different areas (e.g. between urban and rural areas), and there is also a financial element (the average monthly charge is approximately $10 \%$ of the average wage in the Czech Republic (1998), which is a lot for less affluent families to pay.

5) This is a general rule. The only exceptions are government functions and some professions which are considered to be dangerous (explosives, some positions in the military or police, etc.) Women do, however, make up $2 \%$ of the armed forces and in the police force this figure is as high as $10 \%$.

6) According to a new ILO study published by The Economist, 11th September 1999, in 1996 more than $80 \%$ of Czech women worked more than 40 hours per week. This compares with $60 \%$ of women in the USA, $20 \%$ in Germany and $10 \%$ in the Netherlands. 
to pull the country out of economic depression. This means that both the work system and women themselves have little or no interest in changing the existing gender differences in the division of labour.

These features of the economic and social environment are valid for all working women with all levels of education, including those with a university degree. Czech women place considerable value on employment and see no alternative to it. Czech women in fact declare a high degree of interest in paid employment, similar to that of men [survey Muži... 1995]. The most specific feature of the Czech situation is the forms and mechanisms of women's behaviour within the family, which are compatible with women's employment. Both the family and the work system show a clear tendency to suppress or influence what does not directly benefit them [Tuček et al. 1998].

The weak dynamics of social changes in the 1990s in relation to women conceal the contradictions in the social position of women in a transitional society. In view of the risks defining the female role, stagnation is viewed as success. Sociological and demographic surveys which have traced the female perspective in this country in the 1990s in detail have, however, highlighted the "cost of the conditions" under which women maintained their positions [survey Muži... 1995, Fialová and Kučera 1995]. The most important of these include:

1. Delaying marriage and a family;

2. A fall in the fertility rate, postponing having a child (children);

3. Renouncing salary increases and a career;

4. Increased time spent on work;

5. A high percentage of working overtime.

The current position of Czech women on the labour market shows the following characteristics:

1. A large percentage of the workforce has been female throughout the $1990 \mathrm{~s}$ (44.4\% in 1999) and this seems to be rising slightly.

2. The division of labour is determined by the division of certain important segments of the market into male or female.

3. There is no legislation directly concerning discrimination against women in the labour market.

4. Social policy guarantees social protection for pregnant women and women with small children.

5. Unemployment of women rose in the second half of the 1990s (8\%). The level for men is lower $(5 \%)$.

6. The number of women on maternity leave and extended maternity leave fell from 249,698 in 1989 to 170,490 in 1997 , i.e. by $68 \%$.

7. The percentage of women in high positions at work has remained stable throughout the $1990 \mathrm{~s}$ at $3.7 \%$ ( $9.1 \%$ for men).

8. The number of branches which are overwhelmingly female has not changed (6 out of $15)$. 
9. The percentage of working women with a degree has risen slightly during the $1990 \mathrm{~s}$ (1991: women 7.5\% - men 11.2\%, 1998: women 9.6\% - men 12\%).

10. The percentage of university students who were women was still $45 \%$ of the total in 1998.

\section{University Graduates and Other Working Women}

There are fewer than 202,000 working women who have a university education, i.e. $9.6 \%$ of the total number [Trh... 1999: 91]. Both the number and the percentage are influenced by a number of gender factors.

The number of women graduates is so low with respect to the structure of the national economy that the gender-related division of work means that women graduates are dominant in the female sectors of the labour market. What then is the reason for this dominance? The position of university-educated women in the female sectors is not directed by the same 'social automatism' that is in force in the male labour market, but there are clearly social and economic mechanisms at work which create a relatively advantageous and stable environment for woman graduates. The relativity is due to the fact that comparisons concern only $46 \%$ of the labour market. These market mechanisms include:

- a small male presence in professions requiring a degree but with a monopoly of women (e.g. primary or secondary school teachers, judges, and some areas of medicine);

- new jobs for women have appeared which require higher initial capital (higher level of education, age requirements and other social characteristics). Female professions of this type can be performed by women with a secondary school education, but a university degree brings greater prestige in a given position (e.g. administrative secretary, head of the secretariat of private companies);

- the salary structure used in the state sector privileges university education, without any direct relation to the work involved;

- a university degree opens the way to further licences and professional certificates (e.g. a lawyer's licence, scientific honours, trader's licence);

- higher average earnings of university graduates in comparison with unqualified women (299\%, see below) and even those with a secondary education, regardless of gender inequalities on the market;

- the prestige of woman graduates in the Czech Republic is generally high;

- the "particular incidence" of women with a university education (a low percentage in both absolute and relative terms) increases their value and there are segments of the market where graduates are highly regarded and irreplaceable. Their value, importance or irreplaceability is not however reflected in remuneration in this country and there is a widespread discrepancy between the prestige of a profession and the salaries paid in it.

The current work status of women university graduates is the result of the long-term penetration of women into the professions (1948-1998). Women with a university education are in an advantageous position in comparison with other working women. Many female (graduate) professions show a low level of unemployment (1998: 2.9\%), greater stability and a higher number of vacant positions. 


\section{Gender Differences}

With respect to the question of whether gender differences in incomes and employment can be expected to deepen to women's disadvantage, remain the same or shrink, research results indicate that the answer must be sought on several levels:

(1) social

(2) institutional

(3) individual

(1) There is no social consensus in either the work or social environment which would limit the existing criteria of merit. The existing criteria are not however universally shared and are indeed controversial. A transitional society requires deep-reaching changes in social relations, since equality of opportunities is not seen as a value.

(2) In a transitional society, institutions and organisations are strongly pre-coded with the continuing presence of stagnating social relations and show an immense ability to set agendas without any real change. The hidden patriarchal structure of public institutions is a limitation on equal opportunities.

(3) Women in general have virtually no sensitivity to the question of gender differences or the perception of discrimination, and graduates are no exception to this. Qualitative research has shown an almost universal lack of knowledge of feminist or gender perspectives among, for instance, women doctors or teachers [Database... 1996, 1997].

In democratic societies, changes in gender differences (in pay or promotion) are conditioned by economic prosperity and social contracts, both of which are lacking in the Czech Republic.

The following analysis, therefore, takes not only a structural view of salary differences, but also a view of the structure of the attitudes of men and women to questions relating to their careers and performance, an assessment of the work climate, and of the distribution of various forms of capital and capacity by gender.

\section{Women Graduates and Salary Differences}

The salary advantage of men is one of the fundamental gender differences on the labour market. In the Czech Republic it is not possible with the present level of research into these salary differences to show to what degree (in percentages) these salary differences are due to discrimination against women, and to what extent they can be explained by the different distribution of men and women between the professions and sectors of the economy. Most authors tend to argue that while discrimination may well exist, it is difficult to prove [Kuchařová and Zamykalová 1998, Večerník 1998, Dvořáková 1999]. The usual criteria for comparison and the indexes of measurement used internationally today are not used in this country.

The rate of the rise of men's average monthly earnings between 1984 and 1997 fell by about 6 percentage points after 1989 in favour of women, but they are still around $135 \%$ of women's average earnings. In 1997 this figure in fact rose to $136.2 \%$. The reverse ratio 'women/men', i.e. of women to men, in that year was $73.4 \%$, which in abso- 
lute terms means that the difference between men's and women's average monthly incomes can rise by as much as 512 crowns in one year. ${ }^{7}$

This description of earnings inequalities offers a whole range of interesting analyses, but I would like concentrate here on the question of salary differences of women with university degrees. There are two main features of the structure of inequality that are of interest: in comparison with women with other levels of education, and with men with the same level of education.

Table 1. Average Monthly Earnings of Men and Women by Education (in CZK)

\begin{tabular}{|c|c|c|c|c|}
\hline Highest educational attainment & Men & Women & $\begin{array}{c}\text { Differential } \\
\text { Women/Men }\end{array}$ & $\begin{array}{c}\text { Average } \\
\text { in } \%\end{array}$ \\
\hline Total & 12,632 & 9,272 & $-3,360$ & 73.4 \\
\hline Without education & 8,004 & 5,370 & $-2,634$ & 67.0 \\
\hline Compulsory & 8,638 & 6,392 & $-2,246$ & 73.9 \\
\hline Secondary vocational & 10,495 & 6,782 & $-3,713$ & 64.6 \\
\hline Secondary technical & 9,936 & 7,558 & $-2,378$ & 76.0 \\
\hline Secondary vocational with GCSE & 11,556 & 8,711 & $-2,845$ & 75.3 \\
\hline Secondary general with GCSE & 14,326 & 10,188 & $-4,138$ & 71.1 \\
\hline Secondary technical with GCSE & 14,355 & 10,580 & $-3,775$ & 73.7 \\
\hline Upper Tertiary education & 14,381 & 10,614 & $-3,767$ & 73.8 \\
\hline University & 21,018 & 14,321 & $-6,697$ & 68.1 \\
\hline Postgraduate & 19,558 & 16,016 & $-3,542$ & 81.8 \\
\hline
\end{tabular}

Source: $\quad[M z d y \ldots 1998]$, own calculations.

Education has a very marked effect on the pay structure and works in favour of women when seen from the point of view of average women's earnings. The earnings of a woman with a post-graduate degree are $173 \%$ of the average woman's wage and $299 \%$ of that of women who did not complete primary school. In comparison with men's earnings, however, all categories of women lose out, women with vocational training the most, followed by those without qualifications and surprisingly by those with a first degree, whose earnings are only $68 \%$ of their male counterparts.

An important factor is the comparison of the weight of education in the differential of men's and women's wages. According to Večerník [1998: 118] "education increases the differential in men's incomes, but decreases in the case of women. While for men individual explanatory factors function independently and can therefore reinforce each other, these factors have a more pronounced effect on women's earnings, but basically only in combination. This means that for women a handicap in one respect (e.g. age) cannot compensate for strengths in another area (e.g. education)." This of course means that there is a considerable discrepancy between male and female university graduates, since for the latter the income effect is lower in other educational categories. If this trend continues it would lead to a paradoxical conclusion: if women climb (in educational terms)

7) Average incomes are given in Czech crowns. The exchange rate to the US dollar varies around the figure of 35 crowns to one dollar. Gross average monthly earnings are compared for all employees. The percentage of employees with over 1700 paid hours per year is $81 \%$ for men and $76 \%$ for women. 
the social status ladder to university education, then they are more likely to suffer discrimination (or gender inequality), since men with similar parameters often receive much higher salaries.

There is of course another relevant circumstance here. As has been shown, for women a post-graduate qualification increases average income, but this is not the case for men (Table 1). In the current 'salary situation' men will not receive major gains from a scientific qualification. This is naturally more linked with (salary) discrimination in science, research and education than in other sectors of the market, since there is a greater number of men and women with such qualifications in these areas. While in the female sectors a post-graduate qualification provides a 'salary advantage' while in the male sectors it is a definite 'salary handicap'.

Higher education is a benefit for women in comparison with other women, but when compared with men, women university graduates have the same level of earnings as men with a secondary school certificate (maturita), i.e. one level of education lower.

Closely connected with the above analysis is the aspect of wage scales (Table 2) which combine years of work and level of education attained. Levels 9 to 12 relate to people with a university degree.

Table 2. Average Monthly Earnings of Men and Women by Wage Scales (in CZK)

\begin{tabular}{|c|c|c|c|c|}
\hline Wage Scale & Men & Women & $\begin{array}{c}\text { Differential } \\
\text { Women/Men }\end{array}$ & $\begin{array}{c}\text { Average } \\
\text { in } \%\end{array}$ \\
\hline Total & 12,632 & 9,272 & $-3,360$ & 73.4 \\
\hline Of which: level 1 & 6,528 & 4,919 & $-1,609$ & 75.3 \\
\hline level 2 & 6,283 & 5,455 & -828 & 86.8 \\
\hline level 3 & 7,731 & 6,689 & $-1,042$ & 86.5 \\
\hline level 4 & 9,396 & 7,509 & $-1,887$ & 79.9 \\
\hline level 5 & 10,708 & 8,514 & $-2,194$ & 71.5 \\
\hline level 6 & 12,079 & 9,077 & $-3,002$ & 75.1 \\
\hline level 7 & 13,316 & 9,830 & $-3,486$ & 73.8 \\
\hline level 8 & 14,039 & 12,277 & $-1,762$ & 87.4 \\
\hline level 9 & 15,187 & 12,274 & $-2,913$ & 80.8 \\
\hline level 10 & 17,455 & 14,277 & $-3,178$ & 81.7 \\
\hline level 11 & 19,768 & 17,621 & $-2,147$ & 89.1 \\
\hline level 12 & 24,059 & 21,960 & $-2,099$ & 91.2 \\
\hline non-scale & 19,257 & 13,006 & $-6,251$ & 67.5 \\
\hline
\end{tabular}

Source: $\quad[M z d y \ldots 1998]$, own calculations.

Gender inequalities should not play any role in wage scales. Nonetheless, even though the structure of gender equality is higher than for the previous indicators (ranging from $71.5 \%$ to $91.2 \%$ ), differences still do exist. Inequality is greatest in the 5th and 7th group, but gender inequality also moves across the wage scale. Women thus very often fall into a lower group than men.

Women are dominant on the scales 1-3 and 7-9 and men on scales 4-6 and 10-12. This means that at two separate levels of education men are on higher scales and more often profit from a better scale wage. The Czech system suffers from a fatal inertia in the placement of men into higher groups and women into lower. If it is taken into considera- 
tion that women are dominant in non-manual occupations - due both to their higher educational capital and certainly also to their other qualifications - and men in manual ones $(80 \%)$, it could be expected that women will be in more advantageous, better paid positions. The reverse is however the truth: in those occupations where women are in a majority they have a lower level of earnings that those women who work in typically male occupations. As the following comparison shows, men are more likely have high and very high incomes.

Table 3. Intervals of the Highest Average Salaries and Distribution by Gender (in CZK)

\begin{tabular}{lrccc} 
Salary Bracket & $\begin{array}{r}\text { Men- } \\
\text { Number }\end{array}$ & $\begin{array}{c}\text { Women- } \\
\text { Number }\end{array}$ & $\begin{array}{c}\text { \% men of total no. \% women of total no. } \\
\text { of men employed }\end{array}$ & \begin{tabular}{c} 
of women employed \\
\hline $16,001-18,000$
\end{tabular} \\
18,751 & 6,875 & 6.18 & 2.5 \\
$18,001-20000$ & 12,096 & 4,071 & 3.99 & 1.5 \\
$20,001-25,000$ & 14,801 & 4,968 & 4.88 & 1.77 \\
$25,001-30,000$ & 5,994 & 1,909 & 1.97 & 0.68 \\
30,001 and over & 8,806 & 2,346 & 2.89 & 0.83 \\
\hline
\end{tabular}

Source: $\quad[M z d y \ldots 1998]$

There are two aspects to these differences. Not only do women represent only $25 \%$ of all those with salaries over $16,000 \mathrm{CZK}$, but the ratio of those earning less than 16,000 to those earning more than that figure is 80:20 for men but 93:7 for women.

A further important factor in comparison is average gross monthly earnings for the main occupational groups in the KZAM/ISCO-88 classification. ${ }^{8}$

Table 4. Average Monthly Salaries by Gender (in CZK)

\begin{tabular}{lrrrrrr} 
& \multicolumn{2}{c}{ MEN } & \multicolumn{2}{c}{ WOMEN } & \multicolumn{2}{c}{ differential } \\
KZAM (ISCO-88) & \multicolumn{1}{c}{ salary } & \multicolumn{1}{c}{$\%$} & salary & \multicolumn{1}{c}{$\%$} & \multicolumn{1}{c}{ /m } & in \% \\
\hline 1 & 28,378 & 9.1 & 16,483 & 3.7 & 11,895 & 58.1 \\
2 & 18,702 & 8.1 & 13,597 & 12.2 & 5,105 & 72.5 \\
3 & 15,643 & 14.9 & 11,517 & 22.3 & 4,126 & 73.6 \\
4 & 12,580 & 2.9 & 10,282 & 15.1 & 2,298 & 81.7 \\
5 & 12,681 & 7.2 & 7,525 & 18.5 & 5,156 & 59.3 \\
6 & 9,671 & 2.1 & 7,995 & 2.4 & 1,676 & 82.7 \\
7 & 11,942 & 32.1 & 8,397 & 7.4 & 3,545 & 70.3 \\
8 & 11,789 & 17.2 & 8,628 & 6.7 & 3,161 & 73.2 \\
9 & 8,785 & 6.4 & 6,775 & 11.8 & 2,011 & 77.1 \\
\hline
\end{tabular}

Source: $\quad[$ Mzdy... 1998, Statistická... 1998], own calculations.

Legend: (1) Legislators, senior officials and managers; (2) Professionals;

(3) Technicians and associate professionals; (4) Clerks; (5) Service workers and shops and market sales workers; (6) Skilled agricultural and forestry workers; (7) Craft and related trades workers; (8) Plant and machine operators and assemblers; (9) Elementary occupations.

8) The KZAM Classification of Occupations by the Czech Statistical Office, 2nd edition, 1996, is compatible with the international ISCO-88 standard. 
The differences in average incomes between the highest status level (senior officials and managers) and the lowest (unqualified occupations) is 323 percentage points for men and 243 for women. Further analysis also confirms the considerable gender difference in both aspects under consideration.

Outline 1. Comparison of average monthly earnings by gender in the KZAM categories in \% (Categories as in Legend for Table 4)
A. men (category 1) : men (category 9)
ratio $=323$
B. women (category 1) : women (category 9)
C. men (category 1$)$ : women (category 1$)$
ratio $=243$
D. women (category 1$)$ : men (category 1$)$
E. men (category 1) : women (category 9)
ratio $=172$
F. women (category 1) : men (category 9)
ratio $=58$
ratio $=419$
G. men (category 2) : women (category 2)
ratio $=188$
H. women (category 2) : men (category 2)
ratio $=138$
I. men (total) : women (total)
ratio $=72.5$
J. women (total) : men (total)
ratio $=136$
ratio $=73.4$

Such a high level of pay differences is not due only the segregation of women into certain jobs. Other inequalities that have been identified include:

a) the creation of gender-specific pay sectors (male and female) in which the proportions are much to women's disadvantage. The peak of the vertical axis is 80 percentage points lower for women than for men;

b) the crisis test (F) shows that on average the earnings of managers are only $188 \%$ those of unqualified men, while a male manager has $419 \%$ of the earnings of an unqualified woman (E). While among unqualified workers the ratio M:W gives men around 2,000 $\mathrm{CZK}$ more than women, the difference for senior officials and managers is around $12,000 \mathrm{CZK}$;

c) in the category of professionals the difference in 5,105 CZK, with men receiving on average $138 \%$ of women's earnings $(\mathrm{G})$;

d) gender differences identified in graduate professions include, for example, that women doctors earn on average only $76 \%$ the salary of their male colleagues, while for women university lecturers the figure is only $85 \%$. The figure for lawyers is $91 \%$, for directors of large companies it is $56 \%$, for directors of small organisations $43 \%$, for chemists $73 \%$, for programmers $82 \%$, etc.

\section{Attitudes to Performance and Careers}

In order to trace these questions, a set of 17 variables was constructed to test the differences between men and women [survey Muži... 1998: Table 5]. ${ }^{9}$

The low values for satisfaction with recognition of performance and salary indicate the high degree of subjective deprivation of university graduates in the Czech Republic, regardless of their sex. There is also, however, a significant difference from the

9) A similar set of variables was constructed during research into working women and men in 1995 [survey Muži... 1995], but the differences identified then were not significant since only $10 \%$ of the sample were graduates. 
gender point of view as the percentage of women who are satisfied is lower than that for men. Only satisfaction with the use of education is relatively high for both sexes. Women are worse off in terms of satisfaction with opportunities for promotion. The prevailing idea that women are not interested in promotion was not confirmed, and women with university degrees were in fact shown to be very interested in this. Only every ninth women said that she had no ambitions for a career, otherwise the percentage was the same as for men. There was, however, a lower percentage of women with a clear career orientation. This important career path is significantly higher among male graduates. This suggests that it is not in fact the strongest factor influencing gender differences between graduates in the Czech Republic, that which sets off the avalanche of male dominance in the professional elite. This dominance can also be seen from career symbols. The Men:Women ratios are clearly unfavourable for women $-65 \%$ of women with a university degree have not received any promotion since 1989. A small group of men (4.2\%) reported high career mobility, while only one woman graduate out of 100 could report this level. Other symbols are secondary sources of income (reported by more than $27 \%$ of men with a degree) or position in upper management $-13.3 \%$ of male graduates. Women also reported less satisfaction with their own abilities (even though the differences are smaller - see Table 5). Men's confidence in their own ability to cope with changes or to resolve problems is high. In all the areas studied, therefore, women with a university degree lose out and questions of performance and career are primarily a male concern, particularly at high levels. There are few women "at the top" and there are many indications that not only is this top career level unattainable because of power, influence or social prestige (of which there is no doubt), but it is also important from the point of view of social models and changes in the implementation of equal opportunities policies. ${ }^{10}$

\section{Evaluation of the Work Climate}

In analysing gender differences in evaluating the work climate, the emphasis was on the differences between subsets of men and women. ${ }^{11}$ The initial supposition was that with the collapse of the planned economy and the transition to a market economy, people with a university education had more opportunities to change their job and for work mobility than did those in other educational categories. The working conditions in which they find themselves today are a mixture of personal choice of a working environment (e.g. between private entrepreneurs and employees in the state sector, or between independent and dependent jobs) and of unavoidable structural, organisational or technological factors arising out of the nature of a concrete job.

\footnotetext{
10) While very stimulating, the discussion of the different forms and courses of career advancement for women and men lies outside the scope of this article. It would be very interesting to trace career paths in a transitional society from the point of view of gender. In our attempts to do so, however, we have come up against the lack of significant data for the female population. Publications on the recruitment of elites in transitional societies do not generally differentiate 'elites' by gender. There is in fact no reason to do so, as elites in the Czech Republic are almost purely male. This is definitely the case in the economic sphere, while the political elite in the 1990 s is only $15 \%$ female.

11) Interesting insights can also be gained from an analysis of individual professions and types of education routes, but this would require considerably more space than is available here and will be published with the overall results of the project.
} 
Table 5. Attitudes to Questions of Performance and Career by Gender (in \%)

Attitude Male Graduates Female Graduates Differential W/M

Satisfaction:

With use of education

76.5

77.5

$+1.0$

With opportunities for promotion 61.0

$\mathbf{5 3 . 5}$

$-7.5$

With recognition of performance 54.4

50.0

$-4.4$

With salary

51.3

41.2

$-10.1$

Importance of Career Mobility:

Most important thing, even at the cost of sacrifice

Career, but in proportion to other interests

8.4

$-7.8$

No career ambitions

73.5

80.4

$+6.9$

Position of Graduates:

Satisfied with the position of graduates in society

Good market recognition

with respect to the demands

of the profession

32.2

Career Symbol: Male Graduates Female Graduates Differential M/W

\section{Total number of promotions:}

None

28.8

52.7

$+23.9$

Several (3 or more)

Number of promotions since 1990:

None

Several (3 or more)

Has subordinates

Top management (more than one department)

Satisfaction with own ability to:

Win recognition

Influence events around self

Cope with changes

Solve problems

Other factors:

Other source of income

27.7

17.7

$-10.0$

Regularly take work home

22.2

28.3 $+6.1$

Note: Attitudes were measured on a 5-point scale and the figures given are the total of the first and second levels.

Source: [survey Muži... 1998].

Men are more likely to work in an unstable and aggressive environment than are women and it was here that the greatest differences were found. The table shows that every fourth man in the sample works in an aggressive work climate, but only every eighth woman. Men are also more likely to see their own position as independent. Aggression and independence are not exclusive to male working environments, and the differences lie rather in the fact that significantly more men than women described their work environment in 
this way. The difference in other features considered are much slighter. The percentages of men and women for the dynamics of the organisation, the style and characteristics of management were approximately the same. (Table 6).

Table 6. Working Climate and Gender Differences (in \%)

\begin{tabular}{lccc} 
& Men & Women & Differential M/W \\
\hline $\begin{array}{l}\text { Environment } \\
\text { Stable and secure }\end{array}$ & 44.1 & $\mathbf{4 9 . 8}$ & +5.7 \\
Unpredictable and unstable & 27.4 & 21.0 & -6.4 \\
$\begin{array}{l}\text { Workplace strategies } \\
\text { Defensive }\end{array}$ & 29.6 & 35.9 & \\
$\begin{array}{l}\text { Aggressive } \\
\text { Management characteristics }\end{array}$ & $\mathbf{2 5 . 5}$ & 13.3 & $\mathbf{- 1 2 . 2}$ \\
$\begin{array}{l}\text { Only orders } \\
\text { High self-motivation }\end{array}$ & 30.8 & 29.7 & -1.1 \\
$\begin{array}{l}\text { Organisational structure } \\
\text { Rigid }\end{array}$ & 33.8 & 31.3 & -2.5 \\
$\begin{array}{l}\text { Dynamic } \\
\text { Management style }\end{array}$ & 28.9 & 29.2 & \\
$\begin{array}{l}\text { Authoritarian } \\
\text { Participatory }\end{array}$ & 35.2 & 32.4 & -0.3 \\
$\begin{array}{l}\text { Own position } \\
\text { Dependent }\end{array}$ & $\mathbf{4 0 . 6}$ & 36.4 & -2.8 \\
Independent & 25.5 & $\mathbf{2 8 . 2}$ & -4.2 \\
\hline
\end{tabular}

Note: $\quad$ A five-point numerical scale was used for each characteristic and the middle response (3) brings it up to $100 \%$

Source: [survey Muži... 1998].

Are the differences found between men and women due to the fact that they work in diametrically opposed work environments, one of which is more demanding? And is it possible to take into consideration a person's own intervention in the nature of the work environment? The research did not provide conclusive answers to these questions. People with a university education are always significantly present at the 'two ends of the scale'. The differences therefore indicate an identification with the prevailing orientation. More men than women work in an exposed environment and place greater emphasis on an authoritarian management style. Women are more likely to see their work climate as participatory. One very important result which reflects the different attitudes in the set is the difference in the way people assessed their own position - more women described theirs as dependent (a difference of 8\%) and fewer women (a 10\% difference) as absolutely independent. Men therefore often have greater space for negotiation and manoeuvre, which they use primarily to gain higher salaries and promotion. These then reinforce their independence and the result is the dominance of men in the management and elite structures. 


\section{Different Forms of Capital ${ }^{12}$}

The research results confirmed that the distribution of various forms of capital among university graduates is influenced by gender (Table 7). Men have an advantage primarily in social and emotional capital, with $80 \%$ of the men in the sample possessing the former. Political-activist capital is also significant as almost every ninth male graduate is a member of a political party and more than one-third are active in associations, clubs, etc. The percentage of women who are members of trade unions is rather irrelevant, as union activity in the Czech Republic is low and formal. The findings on the educational level of spouses or partners were also interesting. More women (60\%) than men (40\%) are likely to have a partner with the same level of education, which means that Czech women are more likely to live in a two-career family than are men. The number of women whose parents had a university degree was also higher.

Unlike women, men are more likely to have a high level of emotional support from their partners (wives) and to be able to rely on their partner's (wife's) positive approach to their work. Far fewer women graduates are likely to possess such emotional capital. It can be supposed that women are more likely to be in a secondary, subordinate position in the family or relationship (as concerns their work in comparison with that of their partner). The differences can be very slight and refined in individual couples where both partners have a degree, but when the partners are forced to make decisions in various everyday situations, then Czech families are more likely to opt for a "serial ranking" than a "parallel ranking", i.e. the man's work first and then that of the woman. When asked about combining work and a family, women more often judged this to be successful. ${ }^{13}$

\section{Conclusions}

In summing up the questions considered and opening the discussion of gender differences among university graduates, it is necessary to go beyond the framework of gender analysis and to restate the relatively low 'gain' in terms of income and prestige of this group of employees in the ten years of transition [Večerník 1998]. There are two problems still remaining: why have people with a university education (men and women) gained so little, and why have women gained even less than men? From the point of view of the division of labour in the economy it is difficult to imagine that market sectors with a predominance of women graduates could emerge when the number of such women is so small. There are, however, quite a few of these, with primary education, pharmacy and justice being the most obvious. There are also some rather less obvious occupations such as paediatricians, university- educated librarians, translators, interpreters and tax advisors.

\footnotetext{
12) The project "Men and Women University Graduates" [survey Muži... 1998] investigated various support mechanisms which play a part in shaping a career. These were termed as "capitals": social, political-activist, family and emotions and in fact include only the variables given in Table 7.

13) The Family Module [survey Rodina... 1994] research project confirmed these conclusions for the majority of Czech families. The research found a certain nostalgia for a traditional model of "the man at work, the woman at home" combined with a very realistic idea of women's contribution to the family budget. This contradiction in the definition of gender roles in the family is also more frequently found among Czech men than among Czech women. University graduates were no exception to this. 
Table 7. Evaluation of Various Types of Capital by Gender (in \%)

\begin{tabular}{lccc} 
Capital & Men & Women & Differential M/W \\
\hline Social & & & \\
Sufficient acquaintances and contacts (YES) & $\mathbf{7 9 . 2}$ & 70.0 & -9.2 \\
Having influence & $\mathbf{4 2 . 5}$ & 36.7 & -5.8 \\
Contact with persons who may be useful & 28.3 & 34.5 & +6.2 \\
Relatives (friends) settled abroad & 31.3 & 30.5 & -0.8 \\
Political-activist & & & \\
Member of a political party & $\mathbf{9 . 3}$ & 3.9 & -5.4 \\
Union member & 13.5 & $\mathbf{2 0 . 9}$ & +7.4 \\
Member of administration & 8.7 & 3.7 & -5.0 \\
Active in foundations, movements, & & & \\
$\quad$ associations, clubs & $\mathbf{3 6 . 0}$ & 23.9 & -12.1 \\
$\begin{array}{l}\text { Family } \\
\text { Percentage of graduates - fathers }\end{array}$ & 24.3 & 26.0 & +1.7 \\
Percentage of graduates - mothers & 11.1 & 14.4 & +3.3 \\
Percentage of graduates - spouses & 40.6 & $\mathbf{5 8 . 7}$ & +18.1 \\
$\begin{array}{l}\text { Emotional } \\
\text { (Perceived) partner's support: WOMEN }\end{array}$ & - & & \\
(Perceived) partner's support: MEN & $\mathbf{6 5 . 5}$ & $\mathbf{4 9 . 0}$ & \\
Positive combination of work and family & 28.6 & $\mathbf{3 6 . 7}$ & +8.1 \\
$\begin{array}{l}\text { Work complicates family life } \\
\text { Positive relation of partner }\end{array} \quad 10.3$ & 7.6 & +2.7 \\
to respondent's work & & & \\
\hline Note: & 28.6 & 23.1 & -5.5 \\
\hline
\end{tabular}

Note: $\quad$ For most variables a dichotomic evaluation - yes/no - was used.

Source: [survey Muži... 1998].

The continuing gender differences between male and female graduates at work cannot be and indeed are not accounted for by the nature of the work force. In this category, these are adapted to the male work force (qualification and practice) and partly to the attractiveness and relative irreplaceability. The secondary position of women graduates on the labour market seems to be due to the following factors:

- there is no real guarantee of the equality of men and women. Legal guarantees of equality are insufficient in the context of a society in transition where the value system is not fully functional and there is not a developed code of merit. Gender differences only become social inequality if there is proof of discrimination or privileged dominance. To prove this it is first necessary to be able to conceive of it, and for the process of proving it to be in the group or public interest.

- there is a double standard of university qualifications which works to the disadvantage of women. This is apparent in the economic and social processes which create separate fields, occupations, positions, professions, etc. for women graduates, with lower requirements on the work force. This mechanism is particularly used (and abused) in the state sector, but at the end of the 1990s even foreign firms have adapted to the 'Czech standard'. implementing different norms for the assessment and employment of women graduates to those which are in force in their home country.

- women are closely linked with the female sectors of the labour market. Employers see the distinction between women graduates and other working women in purely instru- 
mental terms as a division by education. In many respects employers rate women graduates together with less competent employees (assuming them to lack mobility and stability, being unwilling to invest in improving their qualifications, citing the risk of their taking maternity leave, etc.). Various forms of discriminatory practices can be found.

- the "unclear identity" factor. Working women graduates have mostly relinquished the status which their sex gives them in society or even strongly rejected it ${ }^{14}$ [Database... 1995]. They rely on themselves and bear the risks of a group which does not want to be identified with other women on the labour market. They try to make their way in professions or segments of the labour market as individuals (not as a group) but come up against the higher status of men, against the formal and informal male networks, and men's higher social capital.

- the factor of "low emotional support" is present on many levels of social life, including family, partnership relations, the work system, political programmes, the language and media discourse. This refers to the degree of emotional (and social) support which most men, but few women, profit from. This makes it more difficult for women to reach higher positions and is a concealed form of patriarchal practice.

There is a lack of gender equality in graduate professions with a comparable level of qualifications and responsibility. No conflict aimed at parity of status for men and women need be expected, however, as nobody, particularly not women graduates, wants this. In the patriarchal framework strengthened by transitional phenomena, continuity is stronger than discontinuity and inertia stronger than change.

In this social context, where women graduates are redefining their attributed status (as women) but are not able to gain parity of income, mobility and prestige with men of a similar level of education, experience and ability, working women are faced with a high individual risk. In concrete terms this appears in the fact that they must constantly contest the stereotype of women workers but they do not share the advantages of the stereotype of male workers, and they develop highly individual models (modes) of behaviour and movement within the work system. These models are both fragile and risky since they vary widely and do not reflect a group. This is the case, for instance, with the "semiprofessional" form, lowering university qualifications to create a monopoly segment of the market or removing themselves from the stereotypes of women's work as such, as with artists or business women. The highly individualised, personal approaches do make it possible for these "models" to function as personal models and to be imitated within a market sector or profession, but they do not function as social models and are not spread through society. This is particularly the case with elites and high positions and status, which are predefined partriarchally. The recruitment of elites is therefore a matter for men, since the structure and symbols of inheritance are patriarchal. What remains is to open the discussion on the question of whether the position of the middle class in the Czech Republic would improve if a significant part of it was not made up of women. There is no clear answer to this, as certain market segments and professions (in which women predominate) can be shown to have relations (of salaries and promotion) which correspond to the male definition of the field. These are, however, exceptions, anomalies,

14) This is a matter of real subjective perception and it is a paradox that they are constantly confronted with facts that appertain to the female population. 
and the majority of women (graduates) cannot achieve this. On the other hand, most female graduate professions exclude forcible forms of implementation and are shaped by the nature of the work. Their status is therefore limited and they would also lose out in the middle term of the transformation.

The lack of clarity in the presence of women graduates in the work system does however lead to a double burden - one arising from membership of the middle class, the other from gender inequalities. The forms of transitional mechanisms which women graduates are using do not enjoy the support of society and are moreover very individual, so they are suitable only to maintain the gender-determined status, but not to achieve equal status or to implement equal opportunities policies.

Indirect discrimination against women with university degrees are therefore changing the patriarchal causes of lower status for reasons arising out of the transformation processes and the deficits of the transitional society and vice versa.

Translated by April Retter

MARIE ČERMÁKOVÁ works in the Institute of Sociology of the Czech Academy of Sciences. Her main areas of interest are the position of women in Czech society, on the labour market and in the family, gender questions and feminist perspectives in sociology and sociological research. She teaches courses on gender and feminism in the Philosophical and Social Sciences Faculties of Charles University. She is at present the leader of a research team studying "gender in sociology". She has published works in various journals and collections.

\section{Sources of Data}

Ženy v sociální struktuře [Women in the Social Structure] 1991. A sociological survey of working and living conditions of Czech and Slovak women $(\mathrm{N}=$ Czech women 922, Slovak women 408), carried out with the support of the Grant Agency of the Czech Republic

Rodina 1994 [Family Module] 1994. Sociological research into changes in gender roles in the family carried out within the ISSP programme $(\mathrm{N}=$ men 503 , women 521$)$, funded by the Institute of Sociology of the Academy of Sciences of the Czech Republic.

Pracujicí žena a rodina [The Working Woman and the Family] 1995. Sociological survey financed by IREX, looking at connections between family and work in the Czech Republic and in Slovakia ( $\mathrm{N}=$ Czech women 621, Slovak women 338)

Muži a ženy na trhu práce [Men and Women on the Labour Market] 1995. Sociological survey of work relations and attitudes of working men and women, carried out with the support of the Grant Agency of the Czech Republic ( $\mathrm{N}=$ men 495, women 492).

Muži a ženy s vysokoškolským diplomem [Men and Women University Graduates] 1998. Sociological research into the life and work of men and women university graduates, carried out with the support of the Grant Agency of the Czech Republic, considering economically active men and women ( $\mathrm{N}=$ men 961, women 947).

Database of Qualitative Surveys from Various Time Periods 1994-1999, Institute of Sociology, Academy of Sciences of the Czech Republic, Archive of the "Gender in Sociology" team.

\section{References}

Abbot, P., C. Wallace 1997. An Introduction to Sociology: Feminist Perspectives. London: Routledge.

Anker, R. 1998. Gender and Jobs Sex Segregation of Occupation in the World. Geneva: International Labor Office. 
Čermáková, M. 1995. “Gender, společnost, pracovní trh” [Gender, Society, Labour Market]. Sociologický časopis 31: 7-24.

Čermáková, M. 1997a. "Postavení žen na trhu práce" [Position of Women on the Labour Market]. Sociologický časopis 33: 389-404.

Čermáková, M. 1997b. "Rodina a měnící se gender role - sociální analýza české rodiny" [Changing Gender Roles and the Family - A Social Analysis of the Czech Family] Working Papers 97:8. Praha: Sociologický ústav AV ČR.

Dvořáková, Z. 1999. "Ženy a mzdová diskriminace" [Women and Salary Discrimination]. Politická ekonomie 1: 41-50.

"Emerging-Market Indicators" 1999. The Economist, September 11th: 130.

Fialová, L., M. Kučera 1996. "Demografické chování obyvatelstva České republiky během přeměny společnosti po roce 1989" [Demographic Behaviour of the Population of the Czech Republic during the Transformation of Society after 1989]. Working Papers 96:1. Praha: Sociologický ústav AV ČR.

Hakim, C. 1996. Key Issues in Women's Work. London: The Athlone Press.

Jacobs, J. A. (ed.) 1995. Gender Inequality at Work. London: Sage Public., Inc.

Kuchařová, V., L. Zamykalová 1998. Aktuálni otázky postavení žen v ČR [Current Questions of the Position of Women in the Czech Republic]. Praha: VÚPSV.

Machonin, P., M. Tuček 1996. Česká společnost v transformaci [Czech Society in Transformation]. Praha: SLON.

Mzdy zaměstnanců za rok 1997 [Salaries of Employees 1997] 1998. Praha: ČSÚ.

Rees, T. 1998. Mainstreaming Equality in the European Union. London: Routledge.

Rubery, J. 1998. Equal pay in Europe? (ILO Studies). London: Macmillan Press.

Statistická ročenka České republiky '98 [Yearbook of the Czech Republic '98] 1998. Praha: ČSÚ.

Šanderová, J. 1999. "Opět o tř́́dách a vrstvách v současné kapitalistické společnosti” [More on Classes and Strata in Contemporary Capitalist Society]. Sociologický časopis 35: 17-32.

Tuček, M. et al. 1998. “Česká rodina v transformaci - stratifikace, dělba rolí a hodnotové orientace" [The Czech Family in Transformation - Stratification, the Division of Labour and Value Orientations]. Working Papers 98:3. Praha: Sociologický ústav AV ČR.

Trh práce v České republice, Časové rady VǏPS (1993-1998) [The Labour Market in the Czech Republic, Time Series VSPS (1993-1998)] 1999. Praha: ČSÚ.

Večerník, J. (ed.) 1998. Zpráva o vývoji české společnosti 1989-1998 [Report on the Development of Czech Society 1989-1998]. Praha: Academia. 